\title{
Importance of Yeasts in the Mammary Infection of the Cattle in the Region of Sidi M'Hamed Ben Ali, Wilaya of Relizane, Algeria
}

\author{
Akdouche $L^{*}$, Aissi M, Zenia S and Saadi A
}

National Veterinary graduate school of Algiers, Algeria

\begin{abstract}
The mastitis is one of the principal pathologies in the dairy bovine exploitation. The majority of the cases are caused by bacteria, but there are also cases caused by fungi. The objective of our study was to evaluate the occurrence of these fungi in mammary glands of 39 cows (mastitic cows and clinically healthy cows) belonging to two types of farms (4 exploitations using manual milking and 3 exploitations with milking machine) in the area of Sidi M'hammed Ben Ali, Wilaya of Relizane and to assess some risk factors (the tubes of drug, animal excretions, goblets - milkers, the milker hands and the litter). For this purpose, 150 sample of milk and 94 swabs were carried out. Our results revealed the presence of a heavy load of fungi cells in healthy and in the mastistic milks; with a strong frequency of the Trichosporon sp. $(43,58 \%)$ followed by the Candida sp. $(30.76 \%)$. The same yeasts were isolated from swabs.
\end{abstract}

Keywords: Mastitis; Fungi; Antibiotics; Milking machine; The milker; Algeria

\section{Introduction}

Mycotic mastitis was described from the beginning of the last century [1].This mastitis aroused some scepticism and numerous debates because the incriminated agents are often contaminants of the outside or the common saprophytes. Although still badly known, they seem to draw the attention of the pathologists, especially since the everyday acceptance of treatments (intra-mammary antibiotic). The rates of the observed mycotic mastitis vary of $0.34 \%$ [2] in 3.9\% [3,4] accused yeasts of being responsible for $1,76 \%$ of the cases of mastitis (clinic and sub-clinic). Milk resulting from a healthy udder, does not contain either mushrooms or bacteria. It's better to speak about a fungal basic flora, resulting from the environment (dusts resulting from feeds, equipments of collection as well as by those of the animals and even the man) because a healthy milk does not contain, in the physiological state, germs of fungal origin [4]. It is very frequent to find in the unpasteurized milk, the yeasts belonging to the genre Candida and the molds Penicillium which can alter some dairy products.

Mycotic mastitis are split into two big groups according to the moment of appearance: primary mycotic Mastitis [5-7] bacterial preliminary mastitis and secondary mycotic mastitis [8,9] appear often straightaway, without antibiotic treatment or: generally follow upon a bacterial mastitis or upon an intramammary administration of antibiotics by diathélique way. According to some authors [10], the first ones would represent $30 \%$ of the cases and second $70 \%$ of the cases.

In Algeria, very few studies were led on prevalence of the fungal mastitis in the dairy bovine farms as well as various favoring factors their appearance and their development $[11,12]$. So, we settled as objectives, the determination of prevalence of mastitis caused by yeasts and the study of a number of risk factors in some dairy bovine farms of the region of Relizane.

\section{Material and Methods}

\section{Distribution of a questionnaire}

Pre-investigation was realized during the last quarter of year 2007 and the first half of year 2008 to estimate the epidemiological situation of bovine mycotic mastitis in the region of Relizane. For that purpose, a questionnaire was distributed to the veterinarians' practitioners of said region. This investigation concerns the breeding technique, the frequency of the clinical mastitis in these breedings and the percentage of use of antibiotics in the treatment of the clinical mastitis.

\section{Choice of the followed farms}

Four dairy farms with manual milking and tree with machine milking were retained for our study; this selection was based on the comparison of two types of milking. These farms are situated in Sidi M' hammed Ben Ali's region, Daira de Oued Rhiou, wilaya of Relizane, west of Algeria.

\section{Nature and number of samples}

A total of 244 samples were collected by the veterinarians practitioners of Sidi M' hamed Ben Ali's region. That is 150 samples of milk taken from 39 existing cows in 7 farms, all the farms exist in the same region which is the region of Sidi M'hammed Ben Ali , wilaya de Relizène.

The simples were obtained with different mammary glands health status: 19 cows with healthy mammary glands, 15 cows with subclinical mastitis as determinated by the California Mastitis Test(CMT) and 05 cows with clinical mastitis was defined by: swelling, reduced milk flow and abnormal milk appearance, additionally, other signs of infection as fever, inappetence, ataxia.CMT was used to identify subclinical mastitis on mammary gland of the cows.For this stady , milk simples from gland affected with subclinical mastitiswere included when the reaction to CMT was at least grade 1,corresponding with an appearance of viscous milk that does not adhere to the bottom of CMT plate and correlates to 400,000-1,500,000 somatic cells / $\mathrm{ml}$, (6 milk sampling emptied of their tube because badly kept), 91 swabbings [ 39 anal swabs and 35 vaginal

*Corresponding author: Akdouche L, National Veterinary graduate school of Algiers, Algeria, Tel: 0662-54-92-49; E-mail: leilakdouche@yahoo.fr

Received March 03, 2014; Accepted May 07, 2014; Published May 09, 2014

Citation: Akdouche L, Aissi M, Zenia S, Saadi A (2014) Importance of Yeasts in the Mammary Infection of the Cattle in the Region of Sidi M'Hamed Ben Ali, Wilaya of Relizane, Algeria. J Veterinar Sci Technol 5: 172. doi:10.4172/2157-7579.1000172

Copyright: (c) 2014 Akdouche L, et al. This is an open-access article distributed under the terms of the Creative Commons Attribution License, which permits unrestricted use, distribution, and reproduction in any medium, provided the original author and source are credited. 
swabs (4 vaginal swabs badly kept), 2 swabbings on milking machines, 3 on the hands of the milkers and 12 swabbings of creams antibiotics] and at the end 3 samples of litter were got back.

On every cow in lactation: 04 takings of milk (a taking of milk of every trayon), an anal swab, a vaginal swab, only once during all the period of the taking.

In every breeding with manual milking, it made a swabbing of the hands of the milker before the milking (factor of contamination), recovery of the tubes of creams antibiotics (factor of release) used for the treatment of cows with clinical (clinical mastitis: redness, heat, pain) and collect a sample of litter just before its renewal (factor of enrichment). Same taking were made in the breedings with machine milking except swabbing of tumblers milkers of the milking machine (factor of contamination) (Table 1).

\section{Milk sampling}

The correct realization of the sampling procedure was a necessity, regarding the ubiquity of fungi which can contaminate the milk. The characteristics of the atmosphere surrounding were noted: The cow's environment was not loaded of dusts (hays moved nearby, agitated animals). If such was the case, the animals of the dusty premises were taken out. The milk sampling was realized according to the protocol of Guerin and Guerin-faublee [13], which consists in washing itself hands with a disinfecting soap; identify the flask (in wide opening) with the indelible felt-tip: number of the cow, the mammary gland quarter (FR, FL, RR or RL), date and time; the udder was carefully washed and wiped; the rough drafts of milk to rinse the canal of the udder was eliminate (no more than 2 jets otherwise risk of very poor taking in germs); Disinfect the teat canal of the udder with a compress soaked with alcohol in $70^{\circ} \mathrm{C}$; the sterile flask was opened maintaining the opening managed downward. The rubber were kept in the same hand without touching the inside; some milliliters of milk were taken and record the flask; every udder were disinfected before taking the milk of the corresponding district; finally, the takings of milk are kept in $-20^{\circ} \mathrm{C}$ until the day of their analysis.

\section{Mycological analyses of the milk}

The mycological analysis was realized in the laboratory of Parasitology - Mycology of the Veterinary graduate school - Algiers. It consists of a direct examination of the samples of milk after coloring with the blue of the lactophenol. Milk samples were centrifuged and the sediment was inoculated on the surface of Sabouraud Dextrose Agar (SDA) (Pasteur institute of Algiers) added of chloramphénicol and incubated for 3 days at $25^{\circ} \mathrm{C}$. Finally, isolated yeasts and filamentous fungi were identified using microscopic characterization and an auxanogramme performed in a miniature biochemical gallery (Pasteur gallery) (Pasteur institute of Algiers).

\begin{tabular}{|l|c|c|c|}
\hline \multirow{2}{*}{ Nature of the taking } & \multicolumn{3}{|c|}{ Number of samples } \\
\cline { 2 - 4 } & $\begin{array}{c}\text { Manual } \\
\text { milking }\end{array}$ & $\begin{array}{c}\text { Milking } \\
\text { machine }\end{array}$ & Total \\
\hline Number of cows & 17 & 22 & 39 \\
\hline Numbers of milk samples & 65 & 85 & 150 \\
\hline Numbers of anal swabs & 17 & 22 & 39 \\
\hline Numbers of vaginal swabs & 13 & 22 & 35 \\
\hline Number of swabs & 0 & 2 & 2 \\
\hline Number of swabs on the hands of the milker & 3 & 0 & 3 \\
\hline Number of swabs on creams Antibiotics & 12 & 0 & 12 \\
\hline Numbers of litter samples & 0 & 3 & 3 \\
\hline
\end{tabular}

Table 1: Sampling plan.

\begin{tabular}{|c|c|c|c|}
\hline Genre & $\%$ & Species & number \\
\hline \multicolumn{4}{|c|}{ Breeding with manual milking } \\
\hline \multirow[t]{5}{*}{ Candida $s p$} & 25,7 & Candida zeylanoides & 1 \\
\hline & & Candida pseudotropicalis & 5 \\
\hline & & Candida guilliermondii & 1 \\
\hline & & Candida tropicalis & 1 \\
\hline & & Candida parapsilosis & 1 \\
\hline \multirow[t]{2}{*}{ Trichosporon $s p$} & 48,6 & Trichosporon cutanium & 10 \\
\hline & & Trichosporon capitatum & 7 \\
\hline Rhodotorula sp & 8,6 & Rhodotorula rubra & 3 \\
\hline Cryptococcus sp & 2,9 & Cryptococcus terreus & 1 \\
\hline Torulopsis $s p$ & 2,9 & Torulopsis pulcherrima & 1 \\
\hline Penicillium $s p$ & 8,6 & Penicillium sp & 3 \\
\hline Aspergillus sp & 2,9 & Aspergillus sp & 1 \\
\hline Total & 100 & & 35 \\
\hline \multicolumn{4}{|c|}{ Breeding with machine milking } \\
\hline \multirow[t]{5}{*}{ Candida $s p$} & 34,9 & Candida zeylanoides & 1 \\
\hline & & Candida pseudotropicalis & 2 \\
\hline & & Candida guilliermondii & 7 \\
\hline & & Candida tropicalis & 4 \\
\hline & & Candida Iusitaniae & 1 \\
\hline \multirow[t]{3}{*}{ Trichosporon $s p$} & 39,5 & Trichosporon cutanium & 8 \\
\hline & & Trichosporon capitatum & 6 \\
\hline & & Trichosporon fermentens & 3 \\
\hline Rhodotorula sp & 9,3 & Rhodotorula glutinis & 4 \\
\hline Cryptococcus sp & 4,6 & Cryptococcus terreus & 2 \\
\hline Torulopsis sp & 2,3 & Torulopsis glabrata & 1 \\
\hline Penicillium $s p$ & 7 & Penicillium sp & 3 \\
\hline Aspergillus $s p$ & 2,3 & Aspergillus sp & 1 \\
\hline Total & 100 & & 43 \\
\hline
\end{tabular}

Table 2: Various species of yeasts and molds isolated.

Yeast identification was performed taking into consideration morphological characteristics, like formation of chlamydoconidium, pseudohyphae and germinal tube development.

The identification of the fungi colonies were realized as previously. For the genre and the species identification of yeasts, the key of identification of yeasts proposed by Drouhet and Dupont [14].

\section{The anal, vaginal swabs and the material of milking}

The vaginal and the anal excretions were collected by swabbing in the region of the perineum and in the vaginal region. Sowings were carried out by direct scattering of the swab on the surface of the SDA plates added of chloramphenicol. After incubation for 3 days at $25^{\circ} \mathrm{C}$, the colonies of yeasts are identified as previously.

\section{The litter samples}

The collected litter was deposited in one sterilized conical glass cup containing sterile physiological water then the whole was homogenized and left resting for $30 \mathrm{mn}$, some gouts of the sediment are then inoculated on SDA added of chloramphénicol. Cultures were incubated for 3 days at $25^{\circ} \mathrm{C}$.

\section{Results and Discussion}

Fungal cultures were observed in 68 samples of milk (Table 2). 
During period spreading out from December, 2007 till May, 2008, a study was realized on the mammary infection to dairy cows in exploitations of Sidi M' Hamed Be Ali's region (wilaya of Relizane).

During our survey, the mycological examination of the samples of milk and the realized swabs, highlighted the presence of yeasts and filamentous fungi with a higher frequency of yeasts (Table 3), who concord with the literature [15-20]. Indeed, the most frequent yeasts genre were Candida (30, 76\%) and Trichosporon (43, 58\%) (Table 4).

Many authors note that the fungal bovine mastitis is predominantly caused by yeasts [15-20].

The mycological analysis also revealed that, the same genres of yeasts were found in both types of exploitations namely Candida, Trichosporon, Rhodotorula, Cryptocoques, and Torolupsis [21-23] with a hugher frequency for Candida and Trichosporon genres $(30,76 \%$; $43,58 \%$ ), then Rhodotorula with $7,69 \%$, Cryptocoques with $3,84 \%$ (Table 4).

All these fungal agents, with the exception of Rhodotorula have been detected before as pathogenic agents in numerous inquiries on fungal mastitis [24]. Prevalence of the fungal mastitis varies $1 \%$ to $44 \%$ according to authors' number [2,5,25-29].

Global frequency observed on the present study was considered at $45,33 \%$ for the exploitations with clinical mastitis and subclinical mastitis (Table 5), similar results to those of Swinne-Desgain [15]. This frequency may be explained by the animal management put in place in the visited dairy farms in the region of Sidi M' hamed Ben Ali (results of the questionnaire): $60 \%$ of the milkers do not disinfect the hands before and after each milking; the udders were not disinfected before the milking in $45,71 \%$ of the cases; the majority of the farms are hobbled Stalling $(54,85 \%) ; 57,14 \%$ of the farmers use a collective rag for the disinfection of the udder and in $65,71 \%$ of the cases, this rag is not disinfected after each use; $25,71 \%$ of the farmers disinfect their milking material once a week; $17,14 \%$ of the breeders change the cow litters only once a week.

The genre Trichosporon was quoted by several authors as being a

\begin{tabular}{|c|c|c|}
\hline Fungi & Manual milking & Machine milking \\
\hline Yeasts & 40 & 46 \\
\hline Moulds & 08 & 06 \\
\hline Total & 48 & 52 \\
\hline
\end{tabular}

Table 3: Summary of the number of yeasts and filamentous fungi isolated from milk.

\begin{tabular}{|c|c|}
\hline Genres & Percentage (\%) \\
\hline Candida spp. & 30,76 \\
\hline Trichosporon spp. & 43,58 \\
\hline Rhodotorula spp. & 8,97 \\
\hline Cryptococcus spp. & 3,84 \\
\hline Torulopsis spp. & 2,56 \\
\hline Penicillium spp. & 7,69 \\
\hline Aspergillus spp. & 2,56 \\
\hline
\end{tabular}

Table 4: Frequency of fungi isolations in the samples.

\begin{tabular}{|l|c|c|c|}
\hline & Number of milk samples & Positive samples & Frequency \\
\hline Manual milking & 65 & 30 & $46,15 \%$ \\
\hline Machine milking & 85 & 38 & $44,70 \%$ \\
\hline Total & 150 & 68 & $45,3 \%$ \\
\hline
\end{tabular}

Table 5: Frequency positive samples according to the milking procedure. potential pathogenic fungi, in particular the species Tr. capitatum, and Tr. cutaneum [2,3]. The present study highlighted these species with a $43,58 \%$ rate $(23,06 \%$ for $T r$. cutaneum, $16,66 \%$ for Tr. capitatum) widely upper to the rates found in a survey led by Mebarki [11] in the region of Algiers (19,25\%) in dairy exploitations presenting subclinical mastitis. Other authors pointed to lower rates, as Moretti et al. [30], that were able to isolated Tr. capitatum in 31, 2\% of the cases and Tr. cutaneum in $18.72 \%$ in Italy. Aalbaek et al. [17] described 5 cases of mastitis caused by Tr. capitatum in Denmark, what is lower than the present results (13 cases). Costa et al. [21] have discribed 21 mastitis cases caused by Tr. cutaneum, in Brazil.

Concerning the Candida genre, its strong predominance (30,76\%) in the whole of the positive samples, confirm the importance of this yeast genre, often evoked as the main genre in the etiology of mycotic mastitis [3,16-18,20,26,31,32]. This frequency of Candida isolation was lower than that recorded in the region of Algiers by Mebarki [11] (52, 07\%) and in the South of Brazil by Spanamberg et al. [33].

Prevalence of the fungal mastitis according to the milking modality was almost the same: in the manual milking, it is $46,15 \%$ and in the machine milking, it is $44,70 \%$, what means that there is an independence between the positive milk samples and the milking procedure at the beginning of meaning (the difference is not significant, $p>5$ ), It is the Chi-squared test of the independence, used for the comparison between both method (manual milking and machine milking).

This indicates that the problem does not settle at the level of the method of milking but in the conditions of progress of the milking (the factors of enrichments, the factors of releases and the factors of contamination) (Table 5).

\section{Conclusion}

The frequency of fungal mastitis is underestimated in Algeria. The present study reports fungal mastitis found in two types of exploitation (using manual milking or machine milking). The Isolation of the same genre of fungi in an almost similar percentage in both milking systems, confirms the idea. This leads to conclude that the problem of the fungal mastitis is not only connected to the milking modality but is connected to the conduct of farmers and the hygienic practices applied during the milking. The hygiene practices in the stables of the dairy farm do not have to be an additional act in the conduct of the farmers but a regular component of the farm management. With the aim of limiting the arising of the fungal mastitis, it is important to establish a specific diagnosis on healthy and pathological milk to modulate a treatment according to the etiology and the clinical aspect of the mastitis.

\section{References}

1. Klein $E$ (1901) Cité par Loftsgard $G$ et Lindquist $K$.

2. Loftsgard G, Lindquist K (1960) Bovine mycotic mastitis. Acta. Vet. Scand 1 201-220.

3. Fameree L, Swinne-desgain D, Cotteleer C (1970) Mammites, antibiotiques, levures. Ann Med Vet 114: 389-409.

4. Fortier G, Rene C (1990), Mammites Mycosiques des bovins, flore fongique du lait, pathogénie et moyen de lutte. Thèse AIFort.

5. El Molla A, Fayed A, Abdel Halim M, Refai M (1980) Studies on mycotic mastitis in Egypt. J of Egypt Vet Med Assoc 40: 35-41.

6. Thompson KG, di Menna ME, Carter ME, Carman MG (1978) Mycotic mastitis in two cows. N Z Vet J 26: 176-177.

7. Kume T, Homma S, Noda Y, Inoue M, Yamada M (1980) a case report on bovine mastitis caused by Aspergillus fumigatus, J Jap Vet Med Ass 11: 28-29. 
Citation: Akdouche L, Aissi M, Zenia S, Saadi A (2014) Importance of Yeasts in the Mammary Infection of the Cattle in the Region of Sidi M'Hamed Ben Ali, Wilaya of Relizane, Algeria. J Veterinar Sci Technol 5: 172. doi:10.4172/2157-7579.1000172

8. Hakogi E, Yoden M, Hohrai E, Watanabe K, Tabuchi K (1981) Bovine mycotic mastitis, a case caused by Aspergillus fumigatus.Bull. Azabu Univer Vet Med 2: $99-107$.

9. Rahman H, Baxi KK (1983) Prevalence of Candida albicans in bovine mastitis, Indian J Microb Immuno Inf Diseases, 4: 49-50.

10. Bertslinger HU, Schweizer R, Scholer HJ (1964) Hefen als mastitis erreger beim rind.Schweiz; Arch. Tierheilk.

11. Mebarki M (2007) Contribution à l'étude des mammites mycosiques dans quelques élevages bovines laitiers de la région d'Alger. Thèse de Magistère. ENSV.

12. Ksouri S (2008) Contribution à l'etude des mammites fongiques des bovins dans deux élevages laitiers de la region de guelma.Thèse de Magistère.

13. Guerin P, Guerin-faublee V (2007) Les mammites de la vache laitière.

14. Drouhet E, Dupont B (1985) Les champignons levuriformes d'intérêt médical. Laborama, Revu d'information. Avril 21: 3-12.

15. Swinne-Desgain D (1971) Isolement de levures à partir de laits de vache. Cahiers de Med.Vet. 40: 2.

16. Kuo CC, Chang $\mathrm{CH}$ (1993) Isolation of fungi from the mastitic milk of dairy cattle. Journal of the Chinese Society of Veterinary Science 19: 221-227.

17. Aalbaek B, Stenderup J, Jensen HE, Valbak J, Nylin B, et al. (1994) Mycotic and algal bovine mastitis in Denmark. APMIS 102: 451-456.

18. Watts JL (1988) Etiological agents of bovine mastitis. Vet Microbiol 16: 41-66.

19. Lagneau PE, Lebtahi K, Swinne D (1996) Isolation of yeasts from bovine milk in Belgium. Mycopathologia 135: 99-102.

20. de Casia dos Santos R, Marin JM (2005) Isolation of Candida spp. from mastitic bovine milk in Brazil. Mycopathologia 159: 251-253.

21. Costa EO, Gandra CR, Pires MF, Coutinho SD, Castilho W, et al. (1993) Survey of bovine mycotic mastitis in dairy herds in the State of São Paulo, Brazil. Mycopathologia 124: 13-17.
22. Krukowski H, Tietze M, Majewski T, Rózański P (2001) Survey of yeast mastitis in dairy herds of small-type farms in the Lublin region, Poland. Mycopathologia 150: 5-7.

23. Krukowski H, Lisowski A, Rózański P, Skórka A (2006) Yeasts and algae isolated from cows with mastitis in the south-eastern part of Poland. Pol J Vet Sci 9: 181-184

24. Moulinier C (2003) Parasitologie et mycologie médicale, éléments de morphologie et de biologie. E.M. Inter-édition Médicales internationales? Cyti, country.

25. Monga DP, Kalra DS (1971) Prevalence of mycotic mastitis among animals in Haryana. Ind. J. Sc.

26. Farnsworth RJ, Sorensen DK (1972) Prevalence and species distribution of yeast in mammary glands of dairy cows in Minnesota. Can J Comp Med 36 : 329-332.

27. Kumer S, Dhillon SS (1975) Mastitis caused by fungi. Indian Vet J 52: 25-128.

28. Fenizzia D, De anseris $P$, Cicala G (1975) Mastitis bovina subclinica attribuibile ad Aspergillus fumigatus. Atti Soc Ital Sci Vet 29: 664-668.

29. Ramisse J, Brement AM, Lamarre C, Viaud MA, Breard A (1982) Résultats d'une enquête sur les mammites Vendée. Point Vétérinaire 13: 63-73.

30. Moretti A, Pasquali P, Mencaroni G, Boncio L, Piergili Fioretti D (1998) Relationship between cell counts in bovine milk and the presence of mastitis pathogens (yeasts and bacteria). Zentralbl Veterinarmed B 45: 129-132.

31. Richard JL, McDonald JS, Fichtner RE, Anderson AJ (1980) Identification of yeasts from infected bovine mammary glands and their experimental infectivity in cattle. Am J Vet Res 41: 1991-1994.

32. Yeh SG, Chung KY, Cho HT (1988) Prevalence of yeasts in bovine mammary gland infections and teat cups of milking machines. Korean $\mathrm{J}$ Vet Res.

33. Spanamberg A, Wünder EA Jr, Brayer Pereira DI, Argenta J, Cavallini Sanches EM, et al. (2008) Diversity of yeasts from bovine mastitis in Southern Brazil. Rev Iberoam Micol 25: 154-156. 